\title{
Effect of human uterine flushings collected at various stages of the menstrual cycle on mouse blastocysts in vitro
}

\author{
R. J. Aitken and J. B. Maathuis* \\ M.R.C. Unit of Reproductive Biology, 23 Chalmers Street, \\ Edinburgh EH9 $3 E W$, U.K.
}

\begin{abstract}
Summary. Mouse blastocysts were cultured in vitro in a defined medium supplemented with uterine flushings (containing $500 \mu \mathrm{g}$ protein $/ \mathrm{ml}$ ) obtained from normal women at various stages of the menstrual cycle. With one exception (uterine flushing collected on the last day of a menstrual period) blastocyst hatching and attachment were not impaired by flushings collected before or after ovulation.
\end{abstract}

\section{Introduction}

Implantation in the rat and mouse is dependent upon the close synchronization of embryonic and endometrial development (Noyes, Dickmann, Doyle \& Gates, 1963). In these species, as well as in the rabbit (Chang, 1950), sheep (Moore \& Shelton, 1964), cow (Rowson, Moor \& Lawson, 1969) and pig (Webel, Peters \& Anderson, 1970), the uterus exhibits only a short period of receptivity towards the blastocyst. When synchronization is disturbed by more than \pm 2 days (Adams, 1976), implantation rarely occurs.

These findings have formed the basis for a current approach to contraception, which aims at the development of pharmacological agents to accelerate the rate of ovum transport in women (Harper $\&$ Pauerstein, 1976). However, it has not yet been demonstrated that the human uterus exhibits only a limited period of receptivity towards the blastocyst. One of the many physical and biochemical factors presumed to be relevant to the fate of blastocysts in utero is the composition of the uterine luminal fluid. This fluid may contain substances detrimental to blastocysts during part of the oestrous cycle (Chang, 1955) or exhibit embryotrophic properties at the time of implantation (Beier, 1974).

The purpose of the present study was to assess the effect of human uterine flushings on blastocysts in vitro. Because there exist at least some similarities between the blastocysts from different eutherian mammals (Brinster, 1973), and because an investigation with human material was not feasible, mouse blastocysts were used.

\section{Materials and Methods}

Uterine flushings were collected from normal, parous women at various stages of the menstrual cycle by the technique previously described (Maathuis \& Aitken, 1978). The uterus of each subject was flushed with $10 \mathrm{ml}$ of $0.154 \mathrm{M}-\mathrm{NaCl}$. The processing of samples and the indices used to assess the 6 stages of the cycle were as reported earlier (Maathuis \& Aitken, 1978). The degree of contamination with plasma protein in each uterine flushing was calculated (Maathuis \& Aitken, 1978) and samples in which the concentration of contaminating plasma protein represented less than $10 \%$ of the total protein content were selected. The protein content of these samples was adjusted to $500 \mu \mathrm{g} / \mathrm{ml}$ with $0.154 \mathrm{M}-\mathrm{NaCl}$. Of this solution, $0.1 \mathrm{ml}$ was added to $0.9 \mathrm{ml}$ of modified Brinster's medium containing $3 \mathrm{mg}$ bovine serum albumin (BSA)/ml (Bowman \& McLaren, 1970), to give a

\footnotetext{
* Present address: Department of Obstetrics and Gynaecology, Leiden University Hospital, Rijnsburgerweg 10,
} Leiden, The Netherlands. 


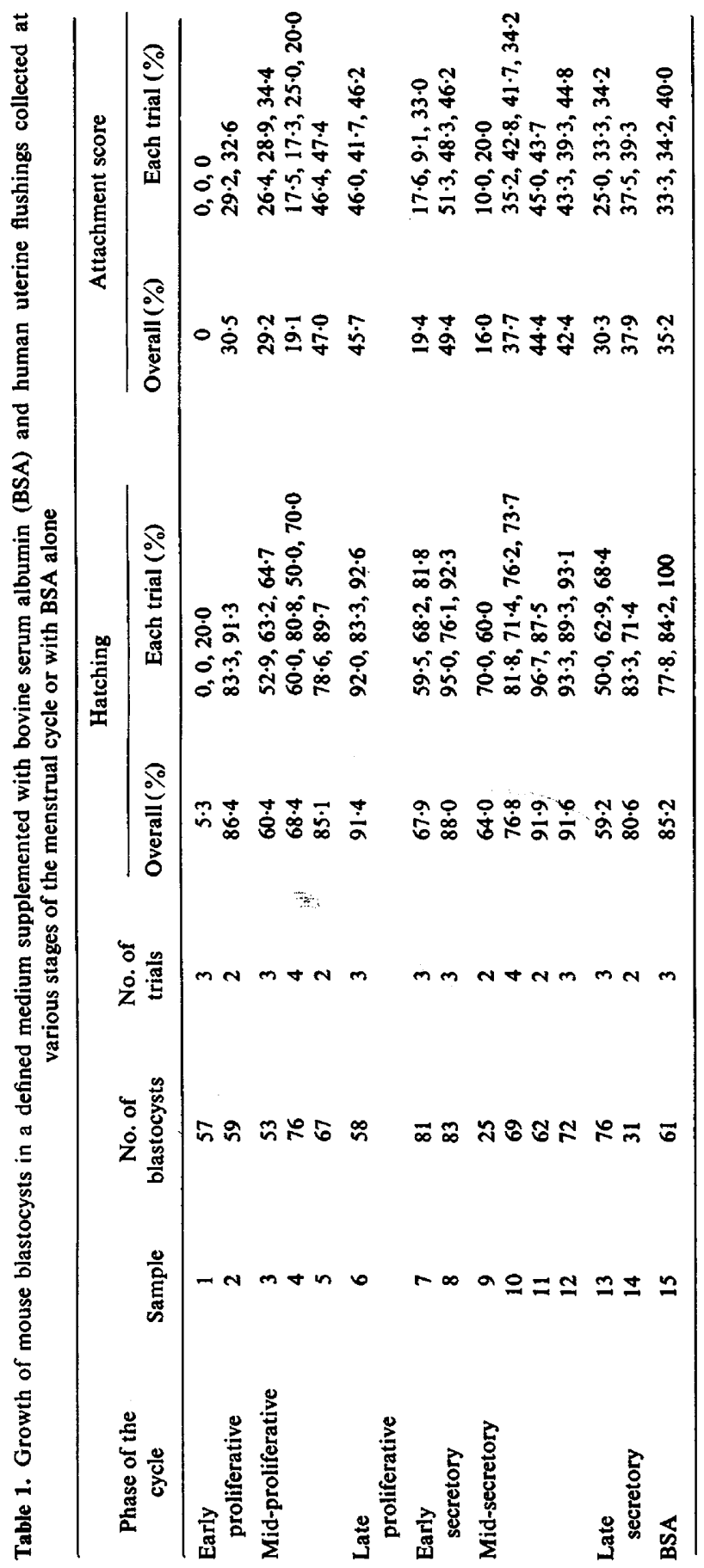


final concentration of $50 \mu \mathrm{g}$ uterine flushing protein/ml culture medium. Supplementation with BSA was necessary because the neat uterine flushings contained concentrations of protein too low to support blastocysts in vitro. This concentration was found in other experiments to be sufficient to permit mouse blastocyst development. The blastocysts were collected 3.5 days p.c. from mice of the random bred $Q$ strain and cultured under paraffin oil in $0.05 \mathrm{ml}$ droplets of medium at $37^{\circ} \mathrm{C}$ in $10 \% \mathrm{CO}_{2}$ in air. Each day the culture dishes were examined microscopically and the number of blastocysts which had hatched from their zona pellucida was determined. An attachment score was obtained by determining the number of blastocysts attached to the substratum ( 1 point), exhibiting giant cell transformation ( 1.5 points) and showing extensive outgrowth ( 2 points). The final result was expressed as a percentage of the maximum possible score (number of blastocysts $\times 2$; Aitken, 1977).

\section{Results}

The results are presented in Table 1. One sample (No. 1), collected from a subject on the last day of menstruation, appeared to be embryotoxic because blastocyst hatching and attachment were consistently inhibited. No marked variation in the effect of the remaining uterine flushings on the behaviour of blastocysts could be detected: hatching and attachment scores in uterine flushings collected before (proliferative phase) and after ovulation were not affected $(P=0.675$ and 0.757 respectively, Wilcoxon's rank test; Snedecor \& Cochran, 1967). Culture medium supplemented with bovine serum albumin gave hatching and attachment scores similar to those in media supplemented with uterine flushings and BSA.

\section{Discussion}

The results of this study seem to indicate that human uterine fluid does not contain substances embryotoxic for mouse blastocysts during most of the menstrual cycle. The effects observed with Sample 1 may be related to lysosomal enzymes known to be released into the uterine lumen during menstruation (Israel, Mishell \& Labudovich, 1970). The reproducibility of the results obtained with Sample 1 suggests that the properties exhibited by the other samples cannot be attributed to the removal or destruction of certain embryotoxic substances during the handling or storage of samples. In addition, similar techniques have been used to demonstrate the embryotoxic nature of uterine fluid recovered from IUD-bearing rats and mice (Breed, 1973).

Mouse blastocysts are known to be fairly undemanding of the conditions for development in vitro, but if the properties of the human luminal fluids in this study are indicative of uterine receptivity towards the human blastocyst, then the results suggest that implantation could occur in the human uterus over much of the luteal phase. This may explain why conception seems to be possible after transplantation of human ovaries to the uterine cavity (Estes \& Heitmeyer, 1934; Preston, 1953).

Our results do not necessarily lead to the conclusion that contraceptive methods aiming at interference with ovum transport in women may prove to be ineffective. Many other factors, such as myometrial activity (Adams, 1976), the organization of the endometrial luminal epithelium and stromal tissue, and blastocyst-endometrial contact (Psychoyos, 1973), undoubtedly play a part in the process of implantation. Nevertheless, it is clearly necessary to establish the duration of endometrial receptivity towards the blastocyst in non-human primates as a prelude to the search for pharmacological agents that accelerate the rate of ovum transport in women.

We are grateful to the Medical Research Council (R.J.A.) and World Health Organization (J.B.M.) for financial support. 


\section{References}

ADAms, C.E. (1976) Egg survival relative to maternal endocrine status. In Ovum Transport and Fertility Regulation, pp. 425-440. Eds M. J. K. Harper, C. J. Pauerstein, C. E. Adams, E. M. Coutinho, H. B. Croxatto \& D. M. Paton. Scriptor, Copenhagen.

AitKen, R.J. (1977) The culture of mouse blastocysts in the presence of uterine flushings collected during normal pregnancy, delayed implantation and prooestrus. J. Embryol. exp. Morph. 41, 295-300.

BeIER, H.M. (1974) Oviducal and uterine fluids. $J$. Reprod. Fert. 37, 221-237.

Bowman, P. \& MCLAREN, A. (1970) Viability and growth of mouse embryos after in vitro culture and fusion. J. Embryol. exp. Morph. 23, 693-704.

BREED, W.G. (1973) Embryotoxic effects of flushes from rat and mouse uteri with or without intrauterine sutures on mouse eggs in culture.J. Reprod. Fert. 33, 353-354.

BrinSTER, R.L. (1973) Nutrition and metabolism of the ovum, zygote, and blastocyst. In Handbook of Physiology, Section 7, Volume II, Part 2, pp. 165-185. Eds R. O. Greep \& E. B. Astwood. Williams \& Wilkins, Baltimore.

ChANG, M.C. (1950) Development and fate of transferred rabbit ova or blastocyst in relation to the ovulation time of recipients. J. exp. Zool. 114, 197225.

Chang, M.C. (1955) Développement de la capacité fertilisatrice des spermatozoides du lapin à l'intérieur du tractus génital femelle et fécondabilité des oeufs de lapine. In La Fonction Tubaire et ses Troubles, pp. 40 52. Ed. P. Funck-Brentano. Masson, Paris.

Estes, W.L. \& HeITMEYeR, P.L. (1934) Incidence of pregnancy following ovarian implantation. $A m . J$. Surg. 24, 563-581.

HARPER, M.J.K. \& PAuerstein, C.J. (1976) Implications for the development of a clinically useful contraceptive. In Ovum Transport and Fertility Regulation, pp. 565-568. Eds M. J. K. Harper, C. J. Pauerstein, C. E. Adams, E. M. Coutinho, H. B. Croxatto \& D. M. Paton. Scriptor, Copenhagen.

ISRael, R., Mishell, D.R. \& Labudovich, M. (1970) Mechanisms of normal and dysfunctional uterine bleeding. Clin. Obstet. Gynec. 13, 386-399.

MAAThuis, J.B. \& AITKEN, R.J. (1978) Cyclic variation in concentrations of protein and hexose in human uterine flushings collected by an improved technique. J. Reprod. Fert. 52, 289-295.

Moore, N.W. \& Shelton, J.N. (1964) Egg transfer in sheep: effect of degree of synchronization between donor and recipient, age of egg, and site of transfer on the survival of transferred eggs. J. Reprod. Fert. 7 , 145-152.

Noyes, R.W., Dickmann, Z., Doyle, L.L. \& Gates, A.H. (1963) Ovum transfers, synchronous and asynchronous, in the study of implantation. In Delayed Implantaion, pp. 197-211. Ed. A. C. Enders. University of Chicago Press.

Preston, P.G. (1953) Transplantation of the ovary into the uterine cavity for the treatment of infertility in women. J. Obstet. Gynaec. Br. Emp. 60, 862-864.

Psychoyos, A. (1973) Endocrine control of egg implantation. In Handbook of Physiology, Section 7, Volume II, Part 2, pp. 187-215. Eds R. O. Greep \& E. B. Astwood. Williams \& Wilkins, Baltimore.

Rowson, L.E.A., Moor, R.M. \& LAwSON, R.A.S. (1969) Fertility following egg transfer in the cow: effect of method, medium and synchronization of oestrus. J. Reprod. Fert. 18, 517-523.

SNEdeCOR, G.W. \& COChRAN, W.G. (1967) Statistical Methods, 6th edn, pp. 130-131. Iowa State University Press, Ames, Iowa.

Webel, S.K., Peters, J.B. \& Anderson, L.L. (1970) Synchronous and asynchronous transfer of embryos in the pig. J. Anim. Sci. 30, 565-568.

Received 30 November 1977 